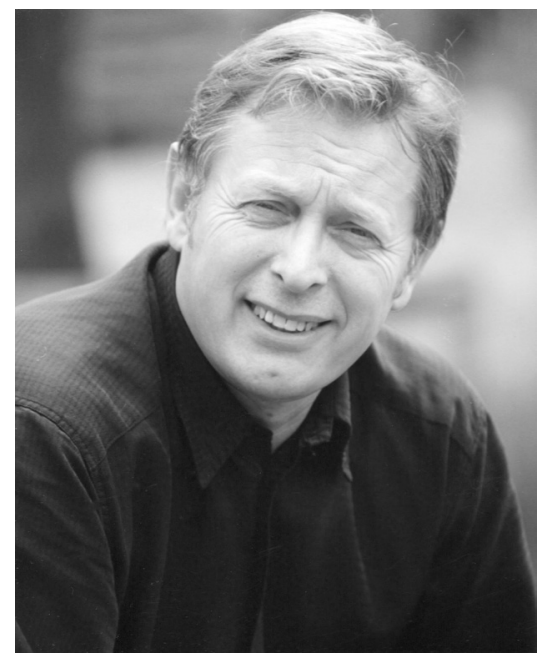

Норман Стоун

Norman Stone

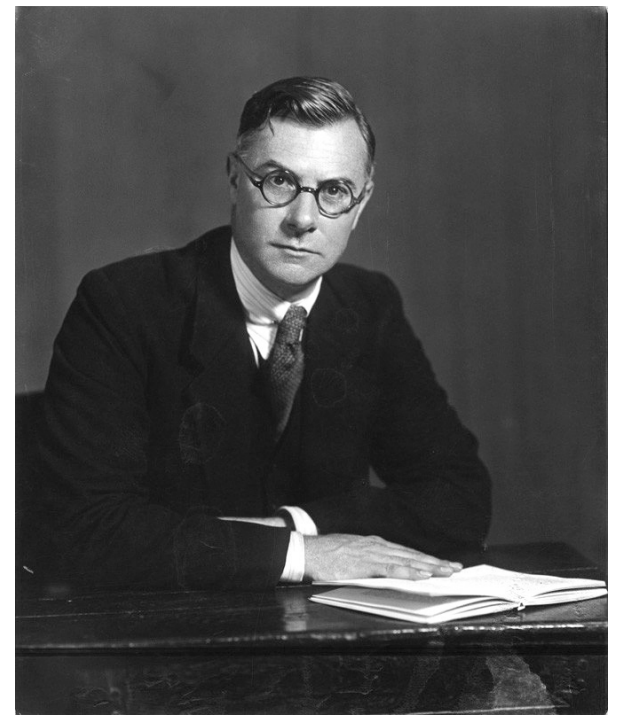

Эдуард Карр

Edward Carr

\title{
Scientia
} et vita 
DOI 10.15826/qr.2015.3.110

УДК 930.2:94(100)"1914/19"+930.2:94(47+57)(09)＜noBreak>：Norman Stone

\section{RUSSIA IN 1914: REASONS FOR DEFEAT AND THE COST OF FUTURE VICTORIES (FROM A DISCUSSION OF BRITISH HISTORIANS)}

In his essay "Russia in 2014: Reasons for Defeat and the Cost of Future Victories (from a discussion of British historians)" Norman Stone, an eminent specialist in Russian history, explores a key period in Russia's fate and explains the reasons for its infamous defeats during World War I and the disastrous consequences thereof not only for the history of the Russian Empire but, ultimately, for the entire world. The author connects into a complex of factors different aspects such as the state of the country's industry, the attitude of the imperial ruling elite, the absence of sufficiently qualified military personnel, and the officers' conservative manner of thinking. According to the scholar, all these existed despite a relatively good state of pre-war Russian economy as a whole.

Apart from a conceptual evaluation the author gives of the war events in some of his works, in the article the reader will find Stone's recollections of debates caused by his arguing that it was wrong to compare the USSR's victory in World War II as a result of Stalin's regime and Russia's defeat in World War I. Stone's claims that Stalinism was pointless and antihuman as well as impossible to justify by means of any economic achievements or propaganda, regardless of the scale thereof, or any dystopian dreams, failed to find support of some of the pro-socialist historians of the postwar era. One of them was Stone's main opponent Edward Carr. Being a recognized sovietologist and author of a fundamental work on the Russian revolution and Soviet history, he became a victim of Stockholm syndrome, i.e. a situation where hostages develop empathy toward the terrorists and are ready to justify their actions. The justification of Stalinism or any other type of dictatorship by any circumstances and an attempt to interpret it as something inevitable was what exasperated the new generation of historians and made them overthrow the existing authorities, and join the "angry young people". Stone's essay describes a single issue of academic controversy 
but it is of great significance for the present day world. The daring character of scholarly thought combined with loyalty to the ideas of humanism are the grounds of research that the modern humanities should be based on. At the end of his essay, Stone wittily quotes George Orwell, a genius that foresaw the collapse of totalitarianism, 'You are always saying that it's impossible to make an omelette without breaking eggs. So where's the omelette?' The view Stone expresses as a researcher and as a person is one that QR supports and we expect it to be welcomed by our multilingual readers.

Keywords: Russian Empire; 1914; revolution; Stalinism; Edward Carr; British historiography of Russia.

Эссе авторитетного английского специалиста в области русской истории Нормана Стоуна «Россия, 1914 г.: причины поражений и цена грядущих побед (из дискуссии британских историков)» касается одной из ключевых страниц в судьбе России, трактуя причины ее бесславных поражений в ходе Первой мировой войны и катастрофические последствия этих событий не только в истории Российской империи, но и, как оказалось, всего мира. Автор связывает в единое целое состояние промышленности страны, позицию имперской властной элиты, отсутствие достаточно подготовленных профессиональных военных кадров, консерватизм офицерского мышления. По его мнению, это парадоксально сочеталось с неплохим уровнем предвоенной российской экономики в целом.

Помимо концептуальной оценки, которую дает автор военным событиям в ряде монографий, для читателя оригинальными являются воспоминания Стоуна о спорах, которые вызвала его позиция о некорректности сопоставлять победу Советского Союза во Второй мировой войне как результат сталинского режима - и проигрыш в предыдущей. Мнение Стоуна о бесперспективности и античеловеческой сущности сталинизма, которую не могут оправдать никакие хозяйственные достижения, никакие усилия пропаганды, никакие утопические мечтания, встретило непонимание у части просоциалистически настроенных историков послевоенного времени. Среди них был главный противник Стоуна Эдуард Карр. Признанный советолог, автор монументального труда о русской революции и советской истории оказался подвержен стокгольмскому синдрому, когда в силу экстремальных переживаний жертвы террористов готовы оправдать самих террористов. Оправдание сталинизма или любого другого типа диктатуры историческими обстоятельствами и попытка его «понять как неизбежность» - вот, что выводило из себя новое поколение историков, заставляло сокрушать авторитеты, вступать в армию «сердитых молодых людей». Эссе Стоуна воссоздает лишь один эпизод научной полемики, но этот эпизод чрезвычайно важен для сегодняшнего дня; дерзость научной мысли в сочетании с верностью гуманистическим идеалам - те основания научного поиска, на которых должна выстраиваться гуманитарная наука современности. Завершая эссе, Стоун эффектно цитирует парадоксальный афоризм Джорджа Оруэлла - гениального пред- 
сказателя катастрофы общества тоталитаризма: «Вы всегда говорите, что невозможно сделать омлет, не разбив яиц. Но где же омлет?»

Эта установка Стоуна как исследователя и человека близка журналу «Quaestio Rossica», и надеемся, что она найдет отклик у разноязычной читательской аудитории.

Ключевые слова: Российская империя, 1914 г., революция, сталинизм, Эдуард Карр, британская историография России.

Forty years ago I published a book called The Eastern Front 1914-1917. It is still in print, and with all its faults, seems to be the only properly scholarly book on the subject: the book deals not just with battles, but with the Russian war economy and the organization of the army. Of course it must be obsolete, and should be replaced, but that is really the Russians' fault: they should have produced an official history decades ago. When I went to the archives in Moscow and complained, I was told that historians would have a terrible time explaining why the war was lost and the army disintegrated. I am glad to learn that at last Russian historians will produce three volumes on this subject, such that my book can be honourably retired from the field.

In the later 1960's and early 1970's, when I worked on The Eastern Front, the subject of the Soviet economy was very fashionable. That world now seems very remote but development economics was all the rage, and the Soviet Union appeared to be a model. How do you escape from the Third World? Communism maybe had the answer. Everyone knew about the costs of Stalinism, but were not Five Year Plans and Collectivization of Agriculture the answer to the perennial problem of the anarchic small peasant? And there was decisive proof of the effectiveness of these. Tsarist Russia had lost her war with Germany. Stalin won his war against Hitler, only a quarter-century later. The great authority in England at the time was E. H. Carr, whose multi-volume history of the Russian Revolution dominated the library shelves [Carr, 1950-1978]. When I was very young, I was under his spell. As a young lecturer on Russian history, with lectures to write that explain the subject to students who know even less than you do, it is quite tempting to present Russian history as a story of backwardness versus great men, or in the case of Catherine the Great, women. You regret the 'excesses' but then point to the 'achievements'. When I wrote about the Russian war effort I was therefore prepared to say that Russia lost the war because the economy was just too weak to stand the strain. Carr approved.

But it was not just the Stalinist historians who said this sort of thing. Tsarist generals also said it. N. N. Golovin was the best-known of them, and he wrote that the army just did not have enough rifles or guns or shell: there were stories of soldiers going into action without rifles, ordered just to pick them up from the dead men in front of them [Головин]. Stavka, after the battle of Lake Narotch in March 1916, was almost paralyzed by the Germans' superiority in armaments: the Northern and Western army groups were more or less inactive in the year leading up to the first Revolu- 
tion in 1917 - conditions quite likely to bring about mutiny. In England, the story of shell-shortage was repeated, to justify the Dardanelles campaign of 1915: open up the Straits, and Russia can export grain again, while foreign munitions can also reach her army. This particular argument was perverse. The Russian army and civilian population needed the grain, lack of which in Petrograd had much to do with the Revolution. And in any case the western armies needed all the munitions they could get, and themselves complained famously about shell-shortage. The White generals' argument was indeed based upon fact, but they too had an interest: their performance had not been brilliant and there had been a long string of defeats, from Tannenberg at the start through Gorlice-Tarnów and the loss of Warsaw in 1915 to the Rumanian disaster at the end of 1916. Was shell-shortage, the weakness of Russian industry, the explanation?

Anyone nowadays would accept that Russia in 1914 was fizzing with life. You only need to look at the architecture of Moscow or Kiev to see that. This was the world's fourth economy, and Russia's growth was cited by the German Chancellor in 1914 as his reason for preventive war: 'Russia grows and grows, and weighs upon us like a nightmare', he said on 7 July 1914 to his private secretary, Kurt Riezler, who recorded it in his diary [Riezler]. The generals said that by 1917 Russia would be so powerful that Germany would be crushed: therefore war now. We do not really know the full facts of Russia's growth, because the factory inspectorate was small in number and could only examine factories employing more than fifty people, whereas the Moscow industrial district hummed with small and medium workshops. Why, then, did Russia experience shortages of munitions?

Around 1970 it would not have been possible for me to work in Moscow, but I did find other sources, particularly at the Hoover Institution in Stanford, where they had been collected by Herbert Hoover as his team went round Russia in 1922, giving famine relief. There were war ministry accounts, and documented autobiographies, for instance by Manikovsky, head of the Artillery Department. Foreign observers, especially the French, were well-informed. There were also considerable documentary collections on various battles published in Moscow. Summing it up, I found that by September 1915 Russian war industry was producing a million rounds of shell every month and the figure went up: by August 1916, in the Brusilov Offensive, General von der Marwitz was saying that 'conditions resemble those in the West'. There were huge bombardments, and there was massslaughter in the Kovel marshes. The Russian commanders asked for a truce, to bury their dead, and the Germans refused, on the grounds that these endless corpses would deter future attacks. What was true of shell also applied to other war-goods, and Russians turned out to be quite proficient when it came to aircraft and radio. So what had gone wrong?

The first obvious feature was one common to all warring countries: the assumption that this would be a short war. Bankers announced that industrial, trading countries could not face a long war without tremendous social trouble as exports collapsed. They also said that credit, based on gold- 
standard money, would be limited (the Hungarian finance minister said he could finance the war for three weeks). Very few people foresaw that paper-money would in effect do the financing, and again very few imagined that an income tax of $15 \%$ would be possible - the middle classes would go on strike. Oddly enough the Russian Duma's 'Great Programme' for armaments, in 1913-14, began with the statement that Russia, being largely agricultural, could face a long war better than other Powers. The War Ministry therefore made no plans for an involvement of civilian industry in the production of armaments. It relied on State factories, the best-known that in Tula. 1,000 rounds per gun was thought to be adequate (in the Boer War of 1899-1902 that was a British figure) and the shell was even stock-piled in northern Russia, the parts kept separately for better preservation, and laboriously screwed together, by candle-light, over a three-month period.

There was a further problem, in that Russian defences in Poland were based on fortresses, the largest of them Novogeorgievsk outside Warsaw. 2,000,000 rounds of shell were kept there, and comparable amounts elsewhere, particularly at Kovno. Fortresses, in the 1880's, had perhaps made sense. By 1910, the progress of heavy artillery was such that they could be blown to bits, as happened with every fortress in Europe - Liege, for instance - except for Austrian Przemysl, where the ground was so muddy that guns could not be moved. But military establishment conservatism ruled out any destruction of such white elephants. In 1915, one after another, they collapsed in short order - Novogeorgievsk in two days, Kovno in one.

Early on, there was also a conviction in the Artillery Department that the infantry were being cowardly, as officers expected gunners to do work that more properly belonged to infantry. Demands for more shell were not taken seriously. This was a period when military establishments were desperate not to be seen to be wasting money, and to avoid parliamentary enquiries into their financial ways. Stavka asked the War Ministry for new type-writers, and was told that, as the war would be short, the old ones would have to do. In similar vein, the State finances were damaged by a decree that alcohol would be forbidden for the duration of the war, unless foreigners were present. Foreigners became popular by November 1914, the British representative at Stavka was recording that 'the Grand Duke gave me a vodka that went down my throat like a torch-light procession'. Such were the illusions of 1914, and there were many others. When the War Ministry did accept that there was a problem of shell-shortage, the immediate response was to invite imports from abroad. The War Ministry did not trust Russian entrepreneurs, who offered their services but also said that they would need an advance for investment in industrial plant. Russian missions came to England and France to place orders. But these countries were all busy producing for themselves, and anyway suffered from much the same problems as Russia. The United States was also busy producing for the British. In any case, how were the Russians to pay? It took months and months for the British to underwrite such expenses, the more so as 
Russian orders competed with their own and drove up prices. They insisted on taking much of the Russian gold reserve as backing, and when it arrived at Liverpool, there was no-one from the Russian embassy to receive it. To summarize a complicated story, only ten per cent of Russia's foreign orders had reached Archangelsk by March 1917.

As the Turkish proverb has it, one disaster is better than a thousand pieces of advice, and so it proved in the summer of 1915. The army had done on the whole badly against the Germans, but very well against the Austrians; it stood more or less on the Carpathian mountains, and threatened Budapest by Easter 1915. Then the Germans transferred an army to the Austrian front, and struck at a very weak point in the Russian line, at Gorlice in south-western Poland. The break-through here led to a Russian collapse, which allowed the Germans into Lithuania and the Austrians into the Ukraine by September. That disaster (and the millions of refugees) galvanized Russia, and private industry was brought into war-production. The results were respectable, and by June 1916, when competent generals emerged, the Russian army had its great victory. A. A. Brusilov was innovative and imaginative. He commanded the south-western army group, on the Austrian front, and he had thought about the problems of this war - in particular, the importance of surprise, and the need to disrupt the movement of enemy reserves. In a set of extraordinary victories, he destroyed two Austrian armies. True, he lost his touch later on, when he tried frontal attacks and heavy bombardment in the old style, but this was the period of which von der Marwitz spoke: western-front conditions were now applying in the east. Russia had turned the corner.

So what went wrong? Here things become more interesting than some simple explanation of 'backwardness', and bear on the nature of late-Tsarist and early-Soviet Russia. There was a sort of war between lord and peasant. Setting up a general staff was difficult - educated officers, following foreign models, behaved arrogantly towards the sortis $d u$ rang who ran much of the army - two-thirds of the officers had only four years of schooling. They fought over everything, from the maintenance of fortresses to the Higher Attestation Board, which made appointments. Artillery was a central point of dispute, and the infantry even managed to have single batteries under the orders of infantry captains, a proceeding unheard-of elsewhere. There were similar disputes between heavy and light artillery, the bombardment in the battle of Lake Narotch being so ineffective as to be called 'General Smirnov's son et lumière'. These disputes of course affected senior appointments, and compromise candidates were generally astonishingly old, men who threatened nobody. In the circumstances, the emergence of Brusilov was remarkable. But he was astute in his own advancement, and ended as Trotsky's inspector of cavalry. When these quarrels extended to strategy and the control of reserves - as happened in 1915 - they did serious damage to the country's military fortunes. The General Staff men - they mainly ended up in the White Army - were confident that they had the answers, whereas their rivals, whose power-centre was in Sukhomlinov's War Ministry, often 
turned out to be right, as for instance with the scrapping of fortresses: these were white elephants, made obsolete by the progress of heavy artillery. The harassment and imprisonment of Sukhomlinov in 1915 has some connection, here, and it is an odd fact that many of his protégés ended up in the Red Army. They wrote in the 1920's about individual battles.

When I had examined all his, I came back to Cambridge and saw Carr. He at once saw that I was not going to be a worshipper of Stalinist modernization, and he asked, what do you think caused the Revolution? I answered that it must have something to do with inflation, the government's loss of control over its finances. I had read A. L. Sidorov's very thorough book on the subject [Сидоров], and had of course noticed the problem of money losing value - inflation ran to $700 \%$ in 1916-17. This is now a commonplace view: bread queues fuelled the Revolution. But that was more or less that as far as Carr was concerned: we never really spoke again, and when The Eastern Front came out he gave me a three-page hostile review in The New York Review of Books [Carr, 1976]. I did not particularly mind - the book was well-received otherwise - but it was characteristic of Carr to ignore the convention that you do not give a bad review to former student's first book: if need be, you refuse to review, or write privately. So I thought: I will also ignore convention, and will write ill of the dead. I wrote his obituary, over three pages in The London Review of Books (January 1983) [Stone], in an episode that has never been entirely forgotten, and will no doubt one day have a counterpart.

I had been offered two of Carr's books for review. One was his volume on the Comintern, running up to 1934, when that organization recognized that its policy of weakening the German social democrats had been a vast mistake, had let in the Nazis [Carr, 1982]. The other was The Twenty Years Crisis, in which he said that, if Hitler had power, this should be recognized, and efforts made to appease him, even if it meant sacrificing small nations (for which Carr did not have much time) [Carr, 1939]. Carr was later on embarrassed by the book, calling it 'a period piece', as well he might, because, by 1943, after Stalingrad, he was saying much the same, as editorialist in The Times, about Stalin. And that was the point: Carr was a man, as Isaiah Berlin remarked, who would have had us all in camps. I turned my review into a study of Carr overall and talked quite widely to people who had had dealings with him, including his third wife, Betty Behrens, who showed me an extraordinary document that he had written for his psychiatrist, Martin Roth. Everyone had an anti-Carr story, from the military historian John Keegan (who described sadistic tutorials at Balliol College, Oxford) to the librarian of Trinity College, Cambridge (who told me how difficult it was to extract from Carr the small subscription which was owing to the inter-library lending scheme). That Carr's women remembered him without affection was part of this, and Betty Behrens told me how, when she was lecturing in India, Carr had sent a telegram complaining that her favourite cat, put out into the snow, scratched at the plate-glass window and disturbed his work on the Comintern: he had therefore taken it to the 
vet to be put down. But the obituary was not really about Carr as a man, twisted and mean as he was: the problem is far greater, how someone of huge intelligence could fall, in succession, for Hitler and then Stalin. These volumes on the Russian Revolution misled two generations about the nature of Communism, and distorted the history of late-Tsarist Russia. He had done some famous lectures in 1960 on What Is History. To him, it was the history of the winner. Therefore Stalin. He had no time for historians who wondered whether Russia might have taken a different course, under Socialist Revolutionaries or Mensheviks (let alone liberals). Using an analogy with English cricket, he said that no-one would write the history of batsmen who made a duck, i.e. who scored nothing. He died in 1983, after an interview in which he said that killing all these peasants had been a price to pay for modernization. He did not like George Orwell, but Orwell maybe has the last word: it is all very well, saying that you can't make an omelette without breaking eggs, but where's the omelette?

Сорок лет назад была опубликована моя книга под заглавием «Восточный фронт, 1914-1917» (The Eastern Front 1914-1917). Eе переиздают до сих пор - со всеми ее несовершенствами, она, похоже, остается единственным действительно академическим трудом на эту тему, описывающим не только битвы, но и военную экономику России, и организацию армии. Эта книга, конечно, должна была бы уже устареть и уступить место другим, но тут уж виноваты российские ученые: им следовало написать официальную историю этой войны десятки лет назад. Когда я жаловался на это в архивах Москвы, мне сказали, что историкам весьма затруднительно объяснять, почему война была проиграна, а армия распущена. Я рад, что наконец-то российские ученые выпустят трехтомник на эту тему и моя книга сможет уйти на заслуженный покой.

В конце 60-х - начале 70-х, когда я работал над «Восточным фронтом», тема советской экономики была в большом почете. Этот мир кажется теперь весьма отдаленным, но тогда самой горячей темой была экономика развивающихся стран, а Советский Союз представлялся вероятной моделью развития. Как избежать «третьего мира»? Коммунизм, возможно, мог бы ответить на этот вопрос. Все знали цену сталинизма, но не были ли пятилетние планы и коллективизация сельского хозяйства ответом на вечную проблему анархически разрозненных мелких хозяйств? Существовало и убедительное доказательство эффективности такой политики. Царская Россия проиграла войну с Германией; Сталин выиграл войну против Гитлера всего четверть века спустя. Большим авторитетом в Англии был тогда Э. Х. Карр, чья многотомная «История Русской революции» [Carr, 
1950-1978] завладела библиотечными полками. В юности я, несомненно, был очарован им. Будучи молодым преподавателем по русской истории, которому нужно было читать лекции, популярно объясняющие ничего не знающим студентам чрезвычайно сложные темы, я поддался искушению изложить историю России через коллизию между отсталым обществом и великими мужами или, в случае Екатерины Великой, - женщинами. Ты сожалеешь о «крайностях», но затем ловко указываешь на «достижения». Поэтому, когда я писал об участии России в Первой мировой, я был готов сказать о том, что российская экономика была просто слишком слабой, чтобы выдержать расходы, связанные с войной. Карр одобрил мою идею.

Однако об этой проблеме писали не только сталинские историки. Царские генералы говорили то же самое. Самый известный из них Н. Н. Головин писал, что у армии просто не было достаточно винтовок, ружей и боеприпасов: бывали случаи, когда солдаты шли в атаку безоружными, с приказом подбирать винтовки у тех, кого убивали в первых рядах [Головин]. После битвы на озере Нарочь в марте 1916 г. Ставка была почти парализована преимуществом германцев в вооружении: Северная и Западная группы армий практически бездействовали в течение целого года перед первой революцией 1917-го - весьма благоприятные условия для возникновения мятежей. В Англии история с нехваткой боеприпасов была подхвачена, чтобы оправдать кампанию 1915 г. в Дарданеллах: откройте проливы - и Россия снова сможет поставлять зерно, в свою очередь получая для армии иностранные боеприпасы и вооружение. Этот аргумент был, конечно, совершенно извращенным. Российская армия и гражданское население отчаянно нуждались в зерне, недостаток которого в Петрограде стал одной из основных причин революции. В любом случае, западные армии нуждались в боеприпасах и снаряжении всех видов и сами - это широко известно - жаловались на нехватку вооружения. Аргумент генералов Белой армии на самом деле имел под собой основания, но у них был и свой интерес: показав себя в военных действиях не лучшим образом, они потерпели целый ряд поражений, начиная от Танненберга, затем Горлицы-Тарнова и сдачи Варшавы в 1915 г. и заканчивая катастрофой в Румынии в конце 1916-го. Но были ли причинами этих поражений нехватка боеприпасов и слабость российской промышленности?

В наши дни ни у кого не вызывает сомнений, что в 1914 г. Россия жила полнокровной жизнью. Чтобы это понять, достаточно взглянуть на архитектуру Москвы или Киева того периода. Экономика России занимала четвертое место в мире, и ее рост стал поводом для «превентивной войны» германского канцлера: 7 июля 1914 г. он поделился своей печалью с секретарем Куртом Рицлером, позже зафиксировавшим разговор в дневнике: «Россия растет и растет, нависает над нами как кошмар» [Riezler]. Его генералы считали, что к 1917 г. Россия будет столь сильна, что просто сокрушит Германию, - 
следовательно, начинать войну нужно было немедленно. Мы не можем точно оценить весь масштаб предвоенной российской экономики, поскольку инспекторат фабрик был достаточно небольшим и учитывал лишь те предприятия, на которых работало более 50 человек, в то время как московский производственный сектор просто переполняли мастерские малого и среднего размера. По какой же причине Россия испытывала недостаток военного снаряжения?

В 1970 г. у меня не было возможности работать в Москве, но я нашел другие источники, прежде всего в Институте Гувера в Стэнфорде. Эти источники были собраны Гербертом Гувером, когда он со своей командой оказался в России в 1922 г. вместе с помощью голодающим. Я нашел документы военного министерства и официальные автобиографии - например, генерала от артиллерии Маниковского. Иностранные наблюдатели, особенно французы, были превосходно информированы. Существовали также обширные опубликованные в Москве собрания документации по различным сражениям. Обобщив свои разыскания, я понял, что к сентябрю 1915 г. российская промышленность производила миллион единиц снарядов ежемесячно, и эта цифра росла: в августе 1916 г., во время Брусиловского прорыва, генерал фон дер Марвиц заметил, что «обстановка здесь стала похожа на Западный фронт». Велись массированные обстрелы, и была массовая бойня в Ковельских болотах. Российские командиры просили о перемирии, чтобы похоронить погибших, но немцы отказались, полагая, что такое количество тел сдержит атаку. Все сказанное о боеприпасах касалось и военной продукции в целом: русские показали большие успехи в отношении самолетов и радио. Так что же пошло не так?

Первая очевидная причина была общей для всех стран, участвовавших в этой войне: расчет на то, что война будет короткой. Банкиры объявили, что промышленным и активно торгующим странам длительная война грозит серьезными социальными потрясениями, связанными с прекращением экспорта. А также что кредиты, обеспеченные золотым стандартом, будут ограничены (венгерский министр финансов сказал, что может финансировать войну в течение трех недель). Очень немногие предвидели, что бумажные деньги на самом деле смогут продолжить финансирование, и очень немногие допускали, что подоходный налог в 15 \% будет возможен - средние классы должны были забастовать. Как ни странно, «Большая программа вооружения русской армии», принятая в 1913-1914 гг. российской Думой, начиналась с заявления, что Россия, будучи глубоко сельскохозяйственной державой, гораздо больше способна выдержать длительную войну, чем остальные стороны. Военное министерство, таким образом, не планировало вовлекать гражданский производственный сектор в производство вооружения. Оно рассчитывало на государственные заводы, известнейший из которых находился в Туле. Тысяча пуль на одно ружье считались достаточным количе- 
ством (такими же были цифры британской армии в Англо-бурской войне 1889-1902 гг.), снаряды складировались на севере России - их держали в разобранном виде для лучшей сохранности, а после в течение трех месяцев не спеша собирали вручную при свете свечей.

Другая проблема заключалась в том, что русские укрепления в Польше были построены на базе крепостей: самое крупное находилось в Новогеоргиевске, под Варшавой. Там держали два миллиона единиц снарядов; и в других местах, особенно в Ковно, не меньше. Возможно, в 1880 г. в крепостях и был смысл, но к 1910 г. прогресс тяжелой артиллерии позволял разносить их в мелкий щебень, что и произошло практически со всеми крепостями в Европе, например с Льежем. Этой участи избежал только австрийский Пшемысль, где почва превратилась в топкую грязь, помешав передвинуть орудия ближе. Но консерватизм военного руководства не позволял отказаться от этих дорогостоящих, хотя и бесполезных сооружений. В 1915 г. эти крепости были уничтожены одна за другой в самое короткое время: Новогеоргиевск за два дня, Ковно - за один.

В начальный период войны в артиллерии бытовало мнение, что пехота ведет себя крайне трусливо, ожидая от артиллеристов той работы, которую по праву должна была делать сама. Требования подвезти больше боеприпасов не воспринимались всерьез. Это был период, когда военные отчаянно старались не производить впечатления растратчиков, чтобы не допустить парламентского рассмотрения их финансовых схем. Ставка попросила у военного министерства новые пишущие машинки, но ей ответили, что, поскольку война будет короткой, можно обойтись и старыми. В свою очередь, государственная казна была подорвана декретом о запрете алкоголя на протяжении всей войны, кроме случаев, когда в компании были иностранцы. К ноябрю 1914 г. иностранцы вдруг стали чрезвычайно популярны, и британский представитель в Ставке записывал: «Великий князь дал мне водки, которая прошлась по моему горлу как факельное шествие». Таковы были иллюзии 1914 г; были и другие. Когда военное министерство наконец признало, что существует проблема нехватки боеприпасов, его немедленной реакцией было начать импорт из-за границы. Военное министерство не доверяло российским предпринимателям, которые, предложив свои услуги, попросили аванс для немедленной инвестиции в заводы. Российские представители отправились в Англию и Францию, чтобы разместить заказы, но производственные мощности этих стран были заняты выпуском боеприпасов для собственных нужд; к тому же они и сами страдали от проблем, подобных российским. Соединенные Штаты были также заняты производством для Британии. В любом случае, как русские собирались платить? Британии потребовалось несколько месяцев, чтобы увериться в гарантиях таких больших расходов, тем более что российские заказы конкурировали с их собственными и цены ползли вверх. Британия настояла на том, чтобы принять немалую часть рос- 
сийского золотого запаса в залог оплаты, но когда золото прибыло в Ливерпуль, там не оказалось никого из русского посольства, чтобы получить его. Обобщением этой сложной истории может служить такой факт: лишь один процент иностранных заказов России достиг Архангельска к марту 1917 г.

Есть турецкая поговорка о том, что одно несчастье лучше тысячи советов, и лето 1915 г. это подтвердило. Русская армия в целом плохо показала себя в противостоянии с немцами, но отлично с австрийцами; она более или менее держалась за Карпаты и к Пасхе 1915 г. уже грозила Будапешту. Потом немцы передвинули свою армию на Австрийский фронт и ударили по очень слабой точке в русской линии обороны — в Горлице на юго-западе Польши. Горлицкий прорыв привел к краху российских усилий, и к сентябрю этого же года немцы вошли в Литву, а австрияки - в Украину. Эта катастрофа (а также миллионы беженцев) стала для России стимулом, и частный сектор промышленности ринулся выпускать военную продукцию. Результаты были впечатляющие, и к июню 1916 г., когда компетентные генералы наконец взяли командование в свои руки, у России появилась и своя большая победа. Генерал А. А. Брусилов был инноватором и обладал большим воображением. Он получил командование юго-западной группой войск на Австрийском фронте, и отлично обдумал проблемы этой войны, в частности важность неожиданного маневра и необходимость помешать движению вражеского резерва. Несколькими блестящими победами он сокрушил две австрийские армии. Да, он потерял свой талант позже, когда пытался одержать следующие победы лобовыми атаками и тяжелыми обстрелами в стиле «старой школы», но ведь это был период, о котором фон дер Марвиц сказал: «Условия Западного фронта теперь применимы и на Восточном». Россия перешла критическую точку.

Так что же пошло не так? Думается, есть более интересная версия, чем объяснять неудачи российской армии «отсталостью». Эта версия опирается на природу позднеимперской и раннесоветской России. Существовало своеобразное противостояние между помещиком (lord) и крестьянином. Организовать генералитет было сложно: образованные офицеры, следуя заграничной модели поведения, вели себя надменно по отношению к sortis $d u$ rang ${ }^{1}$, осуществлявшим командование большей частью всей армии (две трети офицеров имели образование не выше четырех классов). Они конфликтовали по любым вопросам - от содержания крепостей до Высшей аттестационной комиссии, которая занималась назначениями. Артиллерия была центральным пунктом этой подковерной борьбы, а пехота умудрялась даже получать в распоряжение единичные батареи под командой пехотных капитанов - структура, невиданная в других армиях.

\footnotetext{
довых.

${ }^{1}$ Sortis du rang ( $р$. «из ряда») - дослужившиеся до офицерского звания из ря-
} 
Подобные тяжбы имели место и между тяжелой и легкой артиллерией: во время сражения у озера Нарочь обстрел был настолько неэффективным, что его назвали «son et lumiere ${ }^{2}$ генерала Смирнова». Эти споры, конечно, влияли на назначения высшего эшелона, и кандидаты, по которым был достигнут компромисс, обычно оказывались как на подбор дряхлыми стариками, которые никому не могли показаться угрозой. В подобных обстоятельствах восхождение Брусилова было замечательным исключением, и впоследствии этот человек закончил свою карьеру инспектором кавалерии при Троцком. Когда эти раздоры распространялись на стратегию и контроль над резервами - как это случилось в 1915 г., — они наносили серьезный вред военному делу всей страны. Люди из генералитета, в большинстве своем позже ставшие офицерами Белой армии, были уверены, что у них есть ответы на все вопросы, в то время как их соперники, чей центр был сосредоточен в военном министерстве Сухомлинова, чаще бывали правы - к примеру, предлагая отказаться от дорогих и бесполезных крепостей, потерявших оборонительное значение с развитием тяжелой артиллерии. Преследование и заключение Сухомлинова в тюрьму в 1915 г. имеет прямое отношение к этому разладу; интересно также, что многие из протеже Сухомлинова оказались впоследствии в Красной армии.

Взвесив все эти данные, я вернулся в Кембридж и встретился с Карром. Он сразу понял, что из меня не выйдет поклонника сталинской модернизации, и спросил, что же, по моему мнению, стало причиной революции? Я ответил, что одной из причин должна была быть инфляция, потеря правительством контроля над собственными финансами. Я прочел очень подробное исследование А. Л. Сидорова по этому вопросу [Сидоров] и, конечно, отметил проблему денежной девальвации: инфляция в 1916-1917 гг. достигла 700 \%. Сейчас это общепринятая точка зрения: очереди за хлебом разожгли революцию. Однако для Карра со мною все было кончено: мы никогда больше не разговаривали, и когда «Восточный фронт» вышел из печати, Карр опубликовал неприязненную трехстраничную рецензию в журнале The New York Review of Books [Carr, 1976]. Я в общем-то не возражал: моя книга была хорошо воспринята в научном мире, но это было так характерно для Карра - проигнорировать то правило хорошего тона, что первой монографии бывшего ученика не дают негативную рецензию. Если уж она вам так не по нутру, откажитесь рецензировать или напишите автору в частном порядке. Поэтому я подумал: я тоже поступлюсь общепринятым и напишу плохо о мертвом. Я написал некролог Карра, более трех страниц, в The London Review of Books (февраль 1983 г.) [Stone] этот эпизод никогда не забывался, и, несомненно, однажды и он получит свое продолжение.

\footnotetext{
${ }^{2}$ Son et lumière ( $\varnothing р$. букв. «звук и свет») - театрализованное действо на открытом воздухе.
} 
Мне предлагали на рецензию две книги Карра. Одна из них была исследованием, посвященным Коминтерну в период до 1934 г., когда эта организация осознала, что ее политика ослабления немецких социал-демократов была обширнейшей ошибкой, приведшей к власти нацистов [Carr, 1982]. Вторая книга - «Двадцатилетний кризис», в которой он писал, что, коль скоро у Гитлера была власть, следовало признать ее и приложить усилия к некоторому утолению его желаний, даже если это означало принести в жертву небольшие государства (на которые у Карра не оказалось достаточно времени) [Carr, 1939]. Карр впоследствии стыдился этой книги, называя ее «продуктом своего времени», да и следовало бы, ведь в 1943 г., после Сталинграда, будучи автором передовиц в The Times, он говорил то же самое и о Сталине. Я превратил свою рецензию в размышления о Карре и много общался с людьми, которые были к нему близки, включая его третью жену Бетти Беренс - она показала мне необыкновенный документ, написанный Карром своему психиатру Мартину Роту. У каждого была какая-нибудь своя негативная история с Карром: от военного историка Джона Кигана (который описал садистские учебники Карра в Баллиол-колледже, Оксфорд) до библиотекаря в Тринити-колледже, Кембридж (который поведал, как трудно было добиться от Карра крохотной подписки за пользование межбиблиотечным абонементом). То, что женщины Карра вспоминали о нем без теплоты, было частью его истории. Бетти Беренс рассказала, что, когда читала лекции в Индии, Карр отправил ей телеграмму, в которой жаловался, что ее любимый кот, будучи выставленным на снег, царапался в стеклянную дверь и мешал работать над книгой о Коминтерне, поэтому Карру «пришлось» отвезти кота к ветеринару и усыпить.

Но некролог на самом деле был не о человеческих качествах Карра: проблема была гораздо в большем - в том, каким образом человек столь недюжинного ума мог последовательно увлечься сначала Гитлером, а потом Сталиным. Эти тома, посвященные русской революции, ввели в заблуждение целых два поколения, умалчивая правду об истинной природе коммунизма и донельзя искажая историю позднего царизма в России. В 1960 г. Карр прочел знаменитый курс лекций «Что есть история». Для него история - это история победителя. То есть Сталина. У него не было времени на историков, которые пытались задаться вопросом, могла ли Россия пройти другой путь с эсерами или меньшевиками, не говоря уже о либералах. Используя аналогию с английским крикетом, он говорил, что никто не будет писать историю бэтсмена, «давшего утку» (выбившего ноль очков). Он умер в 1982 г., успев дать интервью, в котором сказал, что убийство всех этих крестьян было необходимой ценой за модернизацию ${ }^{3}$. Он не любил Джорджа Оруэлла, но именно за Оруэллом,

\footnotetext{
${ }^{3}$ См. интервью New Left Review (1978): http://mccaine.org/2009/09/06/edwardhallett-carr-on-history-and-revolution/.
} 
возможно, останется последнее слово: «Вы всегда говорите, что невозможно сделать омлет, не разбив яиц. Но где же омлет?» ${ }^{4}$

\section{Список литературы}

Головин Н. Н. Военные усилия России в мировой войне : в 2 т. Париж, 1939.

Сидоров А. Л. Финансовое положение России в годы Первой мировой войны (1914-1917). M. : AH CCCP, 1960. $580 \mathrm{c}$.

Carr E. H. A history of Soviet Russia. Vol. 1-14. London : Macmillan, 1950-1978.

Carr E. H. The Twenty Years' Crisis, 1919-1939: an Introduction to the Study of International Relations, London : Macmillan, 1939.

Carr E. H. The Twilight of the Comintern 1930-1935. London : Macmillan, 1982.

Carr E. H. The War No One Won // The New York Review. 1976. April 29.

Riezler K. Tagebücher, Aufsätze, Dokumente / hrsg. K. D. Erdmann. Göttingen : Vandenhoeck \& Ruprecht, 1972. 177 S.

Stone N. Grim Eminence // London Review of Books. 1983. Vol. 5. No. 1. P. 3-8.

\section{References}

Carr, E. H. (1939). The Twenty Years' Crisis, 1919-1939: an Introduction to the Study of International Relations, London, Macmillan.

Carr, E. H. (1950-1978). A history of Soviet Russia (Vols. 1-14). London, Macmillan.

\footnotetext{
${ }^{4}$ Автором цитаты является английский писатель Джордж Оруэлл. В рецензии «Катастрофическая постепенность» (“Catastrophic Gradualism”) на сборник политических эссе Артура Кестлера «Йог и комиссар» (Arthur Koestler “The Yogi and the Commissar”), опубликованной в журнале The Common Wealth Review (1945, ноябрь), Оруэлл выступил с протестом против ставшей популярной теории катастрофической посредственности, согласно которой "nothing is ever achieved without bloodshed, lies, tyranny and injustice, but on the other hand no considerable change for the better is to be expected as the result of even the greatest upheaval. History necessarily proceeds by calamities, but each succeeding age will be as bad, or nearly as bad, as the last. One must not protest against purges, deportations, secret police forces and so forth, because these are the price that has to be paid for progress: but on the other hand 'human nature' will always see to it that progress is slow or even imperceptible. If you object to dictatorship you are a reactionary, but if you expect dictatorship to produce good results you are a sentimentalist" («ничего никогда не достигается без кровопролития, лжи, тирании и несправедливости, однако, с другой стороны, нельзя ожидать никаких значительных [исторических. - А. Д.] изменений в результате даже самого великого переворота. История - вне всякого сомнения последовательность случайностей, однако, согласно этой теории, каждая следующая эра будет столь же плоха или почти столь же плоха, как и предыдущая. Поэтому нельзя протестовать против чисток, депортаций, деятельности секретной полиции и так далее, поскольку все это - цена, которую следует заплатить за прогресс; с другой стороны, “человеческая натура" всегда позаботится о том, чтобы этот прогресс был медленным или вовсе невидимым. Если вы возражаете диктатуре, вы реакционер, но если вы ожидаете, что диктатура принесет хорошие результаты - вы сентиментальный тип»).

Оруэлл обрушил на эту позицию всю силу своей послевоенной иронической риторики, он всегда был и оставался ярым антисталинистом, гуманистом, ратующим за права и свободы индивидуальной личности и невозможность принесения людей в жертву режимам.

Афоризм Оруэлла об омлете становится своего рода маркером позиций тех, кто солидарен с его неприятием диктатуры и не готов оправдывать зверства режима какимилибо успехами. Полная популярная цитата звучит так: “The formula usually employed is 'You can't make an omelette without breaking eggs.' And if one replies, 'Yes, but where is the omelette?', the answer is likely to be: 'Oh well, you can't expect everything to happen all in a moment"' (см.: http://georgeorwellnovels.com/essays/catastrophic-gradualism/; здесь же приведена библиография творчества и его сочинения). - Прим. перев.
} 
Carr, E. H. (1976). The war no one won, The New York Review (April 29).

Carr, E. H. (1982). The Twilight of the Comintern 1930-1935. London, Macmillan.

Golovin, N. N. (1939). Voenny'e usiliya Rossii v Mirovoj vojne [Military efforts of Russia in World War] (in 2 vols.). Paris.

Riezler, K. (Erdmann, K. D., ed.). (1972). Tagebücher, Aufsätze, Dokumente. 177 p. Göttingen, Vandenhoeck \& Ruprecht.

Sidorov, A. L. (1960). Finansovoe polozhenie Rossii v gody' Pervoj mirovoj vojny' (1914-1917) [Financial situation in Russia during the First World War (1914-1917)]. 580 p. Moscow, AN SSSR.

Stone, N. (1983) Grim Eminence, London Review of Books, 5/1, pp. 3-8.

Translated by Anna Dergacheva

The article was submitted on 15.06.2015

Норман Стоун,

профессор,

Университет Билькент, Анкара,

Турция
Norman Stone,

Professor,

Bilkent University, Ankara, Turkey 